\section{俩 Heighten Science \\ P U B L I C I T I O N S Corporation ISSN 2639-6653}

\title{
Novel Complication of Nusinersen Treatment: Hyponatremia
}

\author{
Yasemin Coban* \\ Sutcu Imam University, Medical Faculty, Department of Pediatrics, Division of Pediatric \\ Intensive Care, Kahramanmaraş, Turkey
}

*Address for Correspondence: Yasemin Coban, Sutçu Imam University, Medical Faculty Department of Pediatrics, Division of Pediatric Intensive Care, Kahramanmaraş, Turkey, Email: yasemincoban83@gmail.com

Submitted: 03 October 2018

Approved: 12 October 2018

Published: 15 October 2018

Copyright: @ 2018 Coban Y. This is an open access article distributed under the Creative Commons Attribution License, which permits unrestricted use, distribution, and reproduction in any medium, provided the original work is properly cited

Check for updates

\section{Abstract}

There are variations in therapeutic regimens of different liver diseases. The accurate diagnosis ensNusinersen treatment is a novel therapy for spinal muscular atrophy (SMA) type 1 ; consequently, the adverse reactions of the therapy, have not been well known, yet. The present study is a case report that declares a hyponatremia development after the nursinersen therapy. Since the therapy is quite new one and has limited practice, we hope that this rare complication will contribute to the scientific literature.

\section{Introduction}

Nusinersen (SPINRAZA-Biogen; Cambridge, MA, USA) has received the first global approval on 23 December 2016 for the treatment of SMA in paediatric and adult patients in the United States Food and Drug Administration (FDA) [1]. Most common adverse reactions are: lower respiratory tract infection, upper tract respiratory congestion, skin rash, back pain, proteinuria and postlumbar puncture syndrome. Severe hyponatremia was reported before in an infant SMA patient, treated with nusinersen. The researchers reported that, salt was added to his diet during 14 months because of severe and resistant hiponatremia [2]. The present report is another case of hyponatremia due to syndrome of inappropriate antidiuretic hormone secretion (SIADH), induced a single dose of nusinersen treatment.

\section{Case Report}

A 5-month-old boy diagnosed with SMA type 1 was admitted to our pediatric intensive care unit for the second dose nusinersen therapy. He received the first nusinersen therapy two weeks ago. His physical examination and vital signs revealed no abnormalities. Laboratory findings on the day of admission, total blood count, renal and liver function test, random blood sugar, rutine urine examination, serebrospinal fluid (CSF) examination, venous blood gas analysis and serum electrolits except sodium were within the normal limits. Serum sodium concentration in venous blood gas analysis was $110 \mathrm{mmol} / \mathrm{L}$; and this result needed to be confirmed by a subsequent laboratory blood sample analyse. However, serum sodium level was found to be $109 \mathrm{mmol} / \mathrm{L}$, again. There was no history of hyponatremia, suggestive water intake, vomiting or diarrhea, before nusinersen treatment. He was fed with breast milk by a nasogastric tube and gained only 500 gr during the last month. There were no signs of dehydration and generalize/ localize edema. His laboratory findings were as follows: lipid profile and blood sugar are within normal range; blood urea: $3,38 \mathrm{mg} / \mathrm{dL}$; creatinin: $0,04 \mathrm{mg} / \mathrm{dL}$; uric acide: 1,5 $\mathrm{mg} / \mathrm{dL}$; sodium: $110 \mathrm{mmol} / \mathrm{L}$; potassium: $4,2 \mathrm{mmol} / \mathrm{L}$; urine density: 1.002 . His thyroid and adrenal functions were normal. His renal ultrasonography was reported as normal. Further investigations revealed low serum osmolarity $(260 \mathrm{mOs} / \mathrm{L})$, elevated urine 
osmolarity (110 mOs/L) and random urine sodium levels $(30 \mathrm{mEq} / \mathrm{L})$ based on which the diagnosis of SIADH was made. Antidiuretic hormone (ADH) level analyze could not be done at the hospital laboratory. His nutrition was added with table salt and he was discharged on day $5^{\text {th }}$. Follow-up blood tests a week later showed that the results had returned to normal ranges with serum sodium level $132 \mathrm{mmol} / \mathrm{L}$, with added table salt. Firstly, water intake was restricted, then hipertonik salin given to increase the sodium level by $10 \mathrm{mEq} / \mathrm{L}$ within 24 hours. The patient continues to get nusinersen treatment, and can only keeps normal sodium levels with added table salt. Another complication due to nusinersen did not develop.

\section{Discussion}

Spinal muscular atrophy is a genetic disease characterized by muscle weakness resulting from the degeneration of alpha motor neurons in the spinal cord and the brainstem [3]. Usually, SMA is caused by a homozygous deletion of the SMN1 gene, resulting in SMN protein deficiency. The SMN locus contains a paralog SMN2 due to an inverted duplication on human chromosome 5 [4].

Nusinersen is an antisense oligonucleotide that leads to splicing correction of the SMN2 gene [5]. The drug is administered intrathecally at $12 \mathrm{mg}$ and 4 dose loading is recommended at the beginning. Nusinersen gets cleared from CSF into the systemic circulation and is guantifiable for 15-168 days after dosing. Autopsy data exposed the presence of nusinersen in liver, skeletal muscles, and kidney situation show that nusinersen gets cleared from CSF into the systemic circulation. Nusinersen is metabolized via exonuclease- mediated hydrolysis. The mean half-life of nusinersen 63-87 days in the plasma. The primary route of elimination is thought to be via urinary excretion [6].

Adverse effects of novel therapy nusinersen were investigated by large clinical trials such as ENDEAR,CS3A,CHERISH and NURTURE [6]. CS3A clinic trials reported three cases, which developed hiponatremia. One of them is, a four month old girl, who diagnosed SMA type 2, had a developed hiponatremia on $89^{\text {th }}$ days after treatment and on $231^{\text {st }}$ day, Na level was determined as $96 \mathrm{meq} / \mathrm{l}$. This patient was supported with table salt, during 14 months [7]. The other case was a 2 month old boy, a hiponatremi was determined on the $184^{\text {th }}$ day of the treatment. However, the hiponatremia was not thought to be related with the drug and was attributed to bronchiolitis, levetiracetam and high fever [7]. The third patient was 7 month old baby and on $190^{\text {th }}$ day of the treatment, hiponatremia was diagnosed. Since he had weight losses and diagnosed with pneumonia; hiponatremia was not recorded to be associated with nusinersen therapy [7].

Because of these three reports, Center for Drug Evaluation and Research, suggests to control serum sodium, both before and after nusinersen treatment. Nusinersen induced hiponatremia, was admitted in only one case and the mechanism was not explained [7]. In present case, our patient developed a hyponatremia following the first nusinersen therapy and that occured at slowly onset. The patient was examined, with regard to inappropriate secretion of antidiuretic hormone etiological factors, as presented in table 1 , such as pain, nausea, stress, and numerous pharmacological agents and diseases [8]. He was ventilated by using home ventilator, for 3 months but, hyponatremia had not developed until the nusinersen therapy. Consequently, no reason was found to explain the etiology of hiponatremia, except for nusinersen administration.

In conclusion, it is suggested that when developing medicine like nusinersen and other oligonuclear ones, this rarely seen but significant complication that stated in present case should be taken into consideration. In addition, the case report is expected to contribute the related literature, for future implementations. 


\begin{tabular}{|c|c|c|c|c|c|}
\hline $\begin{array}{c}\text { Acute } \\
\text { Conditions }\end{array}$ & $\begin{array}{l}\text { Pulmonary } \\
\text { Disease }\end{array}$ & $\begin{array}{l}\text { Neurological } \\
\text { Diseases }\end{array}$ & Medications & $\begin{array}{l}\text { Malignant } \\
\text { Disease }\end{array}$ & $\begin{array}{c}\text { Hereditary } \\
\text { Causes }\end{array}$ \\
\hline $\begin{array}{c}\text { General } \\
\text { anesthesia }\end{array}$ & $\begin{array}{c}\text { Positive pressure } \\
\text { Ventilation }\end{array}$ & $\begin{array}{l}\text { Meningitis, } \\
\text { encephalitis }\end{array}$ & Carbamazepine & Lymphoma & $\begin{array}{c}\text { Gain of function } \\
\text { mutation } \mathrm{V} 2 \mathrm{R}\end{array}$ \\
\hline Stress & Bronchiolitis & Tumors & Vincristine & Ewing sarcoma & \\
\hline Nausea & Pneumonia & Trauma & Cyclophosphamide & $\begin{array}{l}\text { Carcinoma (lung, } \\
\text { bladder, etc) }\end{array}$ & \\
\hline Pain & Asthma & Hydrocephalus & $\begin{array}{c}\text { Tricyclic } \\
\text { antidepressants }\end{array}$ & & \\
\hline \multirow[t]{7}{*}{ Stress } & Cystic fibrosis & Brain abscess & Narcotics & & \\
\hline & & $\begin{array}{l}\text { Rocky mountain } \\
\text { spotted fever }\end{array}$ & NSAIDs & & \\
\hline & & $\begin{array}{l}\text { Cavernous sinus } \\
\text { thrombosis }\end{array}$ & MDMA (ecstasy) & & \\
\hline & & $\begin{array}{l}\text { Guillain-Barré } \\
\text { syndrome }\end{array}$ & SSRI & & \\
\hline & & $\begin{array}{c}\text { Cerebrovascular } \\
\text { accident }\end{array}$ & Desmopressin & & \\
\hline & & $\begin{array}{c}\text { Subdural } \\
\text { hematoma }\end{array}$ & Ciprofloxacin & & \\
\hline & & & Amiodarone & & \\
\hline
\end{tabular}

For a complete list, see references 1 and 2. MDMA1/43,4-methylenedioxymethamphetmine, NSAIDs $1 / 4$ nonsteroidal antiinflammatory drugs, SSRI 1/4selective serotonin reuptake inhibitor; V2R1/4vasopressin 2 receptor.

\section{References}

1. Biogen Inc. SPINRAZA (nusinersen) injection, for intrathecal use: US prescribing information. 2016; Ref.: https://goo.gl/DjKjoi

2. Spinraza (nusinersen) Prescribing Information. Cambridge, MA: Biogen, 2017.

3. Farrar MA, Park SB, Vucic S, Carey KA, Turner BJ, et al. Emerging therapies and challenges in spinal muscular atrophy. Ann Neurol. 2017; 81: 355-368. Ref.: https://goo.gl/rewjnT

4. Claborn MK, Stevens DL, Walker CK, Gildon B. Nusinersen in the Treatment of Spinal Muscular Atrophy. Methods Mol Biol. 2018; 1828: 69-76. Ref.: https://goo.gl/esiVFr

5. Ottesen EW. ISS-N1 makes the first FDA-approved drug for spinal muscular atrophy. TransI Neurosci. 2017; 8: 1-6. Ref.: https://goo.gl/thWsps

6. Hoy SM. Nusinersen: first global approval. Drugs 2017; 77: 473-479. Ref.: https://goo.gl/kZD3Cu

7. Safety Team Leader Review. NDA 209531. Spinraza (nusinersen). Benefit-Risk Summary and Assessment. Center for Drug Evaluation And Research. Reference ID: 4028770.

8. Jones DP. Syndrome of Inappropriate Secretion of Antidiuretic Hormone and Hyponatremia. Pediatr Rev 2018; 39: 27-35. Ref.: https://goo.gl/VPgG1i 